\title{
IDENTIFIKASI JENIS TIRAM DAN KEANEKARAGAMANNYA DI DAERAH INTERTIDAL DESA HARIA KECAMATAN SAPARUA KABUPATEN MALUKU TENGAH
}

\author{
Sriyanti A. Salmanu \\ Fakultas Keguruan dan Ilmu Pendidikan Universitas Pattimura Ambon \\ E-mail: salmanusriyanti@yahoo.com
}

\begin{abstract}
Abstarak: Tiram memilki peranan yang sangat penting, baik itu secara ekologis dan ekonomis. Secara ekologis tiram dikategorikan sebagai biota penting pembentuk ekosistem.Daerah intertidal merupakan salah satu habitat dari tiram.Daerah intertidal Desa Haria memiliki wilayah pasang surut terbuka dan mendapat pengaruh langsung dari lautBanda yang merupakan habitat bagi tiram. Dari hasil penelitian terdapat 4 jenis yaitu spesies Saccostrea cuculata, Saccostrea echinata, Chama pacifica, dan Isognomon pernadengan rata-rata nilai keanekaragaman adalah 1,3362 yang digolongkan pada keanekaragaman sedang karena nilai keankeragamannya berada pada kisaran 1-3.
\end{abstract}

\section{Kata Kunci: Identifikasi, Keanekaragaman, Tiram, Daerah Intertidal}

Abstract: Oysters have very important role, both ecologically and economically. In ecology, oysters grouped as important organisms in ecosystem formation. Intertidal zone is a habitat of oysters. Intertidal zone at Haria village is an open intertidal which got a direct influence of Banda Sea as a habitat to Oysters. The result of this research was showed that there are 4 species in intertidal zone of Haria village. They are Soccostrea cuculata, Saccostrea echinata, Chama pacifica, and Isognomon perna with average value of diversity is 1.3362 which is moderate diversity because diversity value range is 1-3.

\section{Keywords: Identification, Diversity, Oysters, Intertidal Zone}

Tiram merupakan salah satu hewan laut yang tergolong dalam hewan yang tidak bertulang belakang atau invertebrata. Tiram termasuk dalam filum Mollusca dan tergolong dalam kelas Bivalvia (Nontji 1993). Secara morfologi tiram memiliki sepasang cangkangyang berbentuk tidak sama (inequivalve). Cangkang tersebut berfungsi melindungi matel dan organ bagian dalam lainnya.Hewan ini sering dijumpai pada daerah intertidal, karena daerah ini merupakan bagian dari ekosistem pesisir yang banyak dipengaruhi oleh berbagai komponen, baik biotik maupun abiotik.

Pada daerah intertidal tiram memilki peranan yang sangat penting, baik itu secara ekologisdan ekonomis. Secara ekologis tiram dikategorikan sebagai biota pentingpembentuk ekosistem. Secara ekonomis tiram memilki nilai ekonomis yang tinggi karena hewan ini dapat dimanfaatkan oleh masyarakat untuk dijual maupun dikonsumsi pribadi. 
Salah satu daerah intertidal di pulau Saparua adalah daerah intertidal Desa Haria. Daerah intertidal Desa Haria terletak pada bagian selatan kota Saparua dan merupakan daerah intertidal yang cukup baik, karena memiliki karakteristik perairan pantai yang memiliki wilayah pasang surut yang terbuka dan mendapat pengaruh langsung dari laut banda pada musim timur. Perairan ini merupakan perairan khas daerah tropis karena memiliki beberapa komunitas penting seperti hutan mangrove, padang lamun dan terumbu karang yang sangat menunjang kelangsungan hidup berbagai biota laut.Jenis hewan yang hidup di daerah ini juga sangat beragam, salah satunya adalah tiram. Untuk mengetahui keanekaragaman jenis tiram di daerah ini, maka dilakuan penelitian terkait dengan identifikasi dan keanekaragaman jenis tiram di daerah intertidal Desa Haria.

\section{METODE PENELITIAN}

Penelitian ini menggunakan tipe penelitian deskriptif, untuk mengidentifikasikan jenis tiram dan mengetahui nilai keanekaragamannya pada daerah intertidal Desa Haria. Untuk mengetahui jenis-jenis dan jumlah tiram pada daerah intertidal Desa Haria dibuat garis transek pada stasiun pengamatan dengan panjang $500 \mathrm{~m}$. Garis transek dibentengkan secara vertical dari batas surut terendah ke arah laut. Dimana jarak antara transek adalah $100 \mathrm{~m}$, dan jumlah transek sebanyak 5 garis transek. Pada setiap transek dibuat 5 kuadrat(plot) dengan ukuran 1x1 m dengan jarak antar plot adalah $20 \mathrm{~m}$. Untuk menggidentifikasikan jenis tiram digunakan buku Dharma (2005). Nilai keanekaragaman diperoleh dengan menggunakan rumus indeks keanekaragaman Shannon-Wiiner.

\section{HASIL DAN PEMBAHASAN}

Berdasarkan hasil penelitian dan identifikasi jenis tiram di daerah intertidal Desa Haria ditemukan 4 spesies tiram yang tergolong dalam 4 genus, data klasifikasinya dapat dilihat pada Tabel 1.

Tabel 1. KlasifikasiTiram Yang Terdapat Pada Daerah Penelitian

\begin{tabular}{|l|c|c|c|c|c|c|}
\hline Phylum & Kelas & Ordo & Famili & Genus & Spesies & Jumlah \\
& & & & & & Spesies \\
\hline Mollusca & Bivalvia & Ostreoida & Ostreoidae & Saccostrea & Saccostrea cuculata & 62 \\
\cline { 3 - 7 } & & & Crassostrea & Saccostrea echinata & 30 \\
\cline { 3 - 7 } & & & & Chama & Chama pacifica & 53 \\
\hline
\end{tabular}

Dari tabel tersebut dapat dijelaskan bahwa terdapat 4 jenis tiram di daerah intertidal Desa Haria yaitu spesies Saccostrea cuculata dengan jumlah individu yang ditemukan adalah 62 individu, Saccostrea echinata dengan jumlah individu yang 
ditemukan adalah 30 individu, Chama pacifica dengan jumlah individu yang ditemukan adalah 53 individu, dan Isognomon perna dengan jumlah individu yang ditemukan adalah 31 individu.

Dari data hasil penelitian ke-4 spesies hewan dideskripsikan berdasarkan warna cangkang, deskripsi permukaan cangkang dan tempat tiram menempel. Deskripsi jenis tiram di lokasi penelitian selengkapnya dapat dilihat pada Tabel 2.

Tabel 2. Deskripsi Jenis tiram yang ditemukan pada perairan pantai Desa Haria

\begin{tabular}{|c|c|c|c|}
\hline No & Spesies Tiram & Klasifikasi & Ciri-ciri Morfologi \\
\hline 1. & Saccostrea cucullata & $\begin{array}{l}\text { Klasifikasi } \\
\text { Kingdom : Animalia } \\
\text { Phylum } \quad \text { : Mollusca } \\
\text { Kelas } \quad \text { : Bivalvia } \\
\text { Ordo : Ostreoida } \\
\text { Family } \quad \text { : Ostreoidae } \\
\text { Genus : Saccostrea } \\
\text { Spesies : Saccostrea cucullata } \\
\text { (Born, 1178) }\end{array}$ & $\begin{array}{l}\text { Berdasarkan hasil } \\
\text { penelitian, Cangkang } \\
\text { Saccostrea cucullata } \\
\text { memiliki bentuk tidak } \\
\text { sama, warna cangkang } \\
\text { kunig tua sampai kunig } \\
\text { kecoklatan, Saccostrea } \\
\text { cucullata menempel } \\
\text { pada mangrove sebagai } \\
\text { substratnya. }\end{array}$ \\
\hline 2. & Chama p & $\begin{array}{l}\text { Klasifikasi } \\
\text { Kingdom : Animalia } \\
\text { Phylum : Mollusca } \\
\text { Kelas : Bivalvia } \\
\text { Ordo : veneroida } \\
\text { Family : Chamidae } \\
\text { Genus : Chama } \\
\text { Spesies : Chama pacifica } \\
\text { (Broderip, } 1835 \text { ) }\end{array}$ & 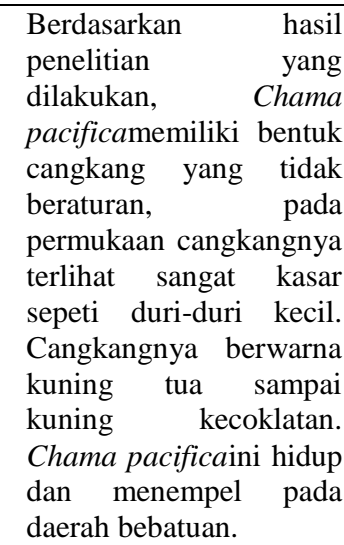 \\
\hline 3. & Isognomon perna & 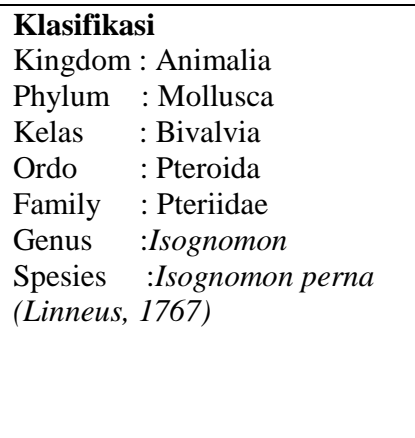 & $\begin{array}{l}\text { Berdasarkan hasil } \\
\text { penelitian, Kedua } \\
\text { cangkang tersebut bersatu } \\
\text { pada bagian punggung } \\
\text { (dorsal) dan dihubungkan } \\
\text { oleh sepasang engsel. } \\
\text { Bagian dalam dari } \\
\text { cangkang berwarna putih, } \\
\text { dan warna cangkangnya } \\
\text { coklat kemerahan. } \\
\text { Isognomon pernahidup } \\
\text { pada daerah bebatuan. }\end{array}$ \\
\hline 4. & Saccostrea echinata & $\begin{array}{l}\text { Klasifikasi } \\
\text { Kingdom : Animalia } \\
\text { Phylum : Mollusca } \\
\text { Kelas } \quad \text { : Bivalvia } \\
\text { Ordo } \quad \text { Ostreoida } \\
\text { Family } \quad \text { : Ostreoidae } \\
\text { Genus } \quad \text { Saccosstrea } \\
\text { Spesies } \quad \text { :Saccostrea echinata }\end{array}$ & $\begin{array}{lr}\text { Berdasarkan } & \text { hasil } \\
\text { penelitian, } & \text { Saccostrea } \\
\text { echinatar } & \text { memiliki } \\
\text { permukaan } & \text { cangkang } \\
\text { bagian luar seperti garis- } & \text { garis radier atau beruas- } \\
\text { ruas, berwarna } & \text { lebih } \\
\text { terang dari } & \text { warna }\end{array}$ \\
\hline
\end{tabular}




\begin{tabular}{|l|l|l|l|}
\hline & (Born, 1778) & $\begin{array}{l}\text { cangkang. Cangkangnya } \\
\text { berwarna kuning } \\
\text { kecoklatan. Saccostrea } \\
\text { echinata hidup dan } \\
\text { menempel pada daerah } \\
\text { bebatuan. }\end{array}$ \\
\hline
\end{tabular}

Berdasarkan hasil penelitian di daerah intertidal Desa Haria rata-rata indeks keanekaragaman jenis tiram pada daerah intertidalsebesar 1.3362. Data selengkapnya dapat dilihat pada Tabel 3.

Tabel 3. Indeks Keanekaragaman Tirampada Daerah Perairan Pantai Desa Haria

\begin{tabular}{|l|l|c|c|c|c|c|c|}
\hline No & \multicolumn{1}{|c|}{ Nama spesies } & Jumlah & ni/ N & Pi & Ln pi & pi Ln pi & H' \\
\hline 1. & Saccostrea cucullata & 62 & $62 / 176$ & 0,3522 & $-1,0435$ & $-0,37$ & 0.37 \\
\hline 2. & Chama pacifica & 53 & $53 / 176$ & 0,3011 & -1.2003 & $-0,36$ & 0.36 \\
\hline 3. & Isognom perna & 31 & $31 / 176$ & 0,1761 & -1.7367 & -0.31 & 0.31 \\
\hline 4. & Saccostrea echinata & 30 & $30 / 176$ & 0,1704 & -1.7696 & -0.30 & 0.30 \\
\hline \multicolumn{6}{|c|}{ Rata- rata } \\
\hline
\end{tabular}

Dari hasil penelitian terkait keanekaragaman tiram yang ditemukan daerah intertidal Desa Haria menunjukkan bahwa nilai rata- rata indeks keanekaragaman 0,33. Kreps (1985) dalam Silulu. P. F. dkk (2013) mengungkapkan bahwa nilai keanekaragaman $\left(H^{\prime}\right)$ rendah jika $H^{\prime}<1$. Maka dapat disimpulkan bahwa nilai keragaman tiram pada daerah intertidal Desa Haria rendah. Irawan (2008) menjelaskan bahwa daerah intertidal merupakan daerah yang mampu di tempati oleh organisme yang bersifat khas. Nilai keanekaragaman tiram pada daerah penelitian rata-rata keanekaragaman adalah 0,33 . Hal ini disebabkan karena tiram merupakan salah satu dari sekian banyak organisme khas yang bisa menempati daerah intertidal Desa Haria.

Rohmimohtarto (1977), menjelaskan bahwa Tiram merupakan salah satu kelompok hewan yang paling luas penyebarannya, yang dapat di temukan pada perairan pasang surut atau laut dangkal. Daerah intertidal Desa Haria memiliki ekosistem yang sangat mendukung kehidupan tiram yang ditemukan, hal ini disebabkan karena daerah intertidal Desa Haria terdiri darikomunitas penting seperti mangrove, lamun danterumbu karang, ketiga komunitas ini sangat menunjang kelangsungan hidup berbagai biota laut. Karena pada daerah tersebut, digunakan oleh biota laut laut untuk melakukan pemijahan, tempat berlindung dan mencari makan.

Martoyo dkk, (2007) menyatakan bahwa tingginya keanekaragaman jenis menunjukan bahwa komunitas tersebut memiliki kompleksitas yang tinggi, karena dalam komunitas tersebut terjadi interaksi spesies yang tinggi. Komunitas yang mempunyai keanekaragaman jenis tinggi akan terjadi interaksi spesies yang melibatkan transfer energy (rantai makanan), predasi, kompetisi, yang sangat kompleks. Sejalan dengan itu Odum (1998), juga mengungkapkan bahwa suatu komunitas dikatakan memiliki keanekaragaman yang tinggi jika komunitas itu disusun oleh banyaknya spesies. 
Sebaliknya suatu komunitas dikatakan memiliki keanekaragaman rendah jika komunitas itu disusun oleh sedikit spesies dan ada spesies yang dominan.

\section{KESIMPULAN}

Dari hasil penelitian ditemukan 4 jenis tiram di daerah intertidal Desa Haria yaitu spesies Saccostrea cuculata, Saccostrea echinata, Chama pacifica, dan Isognomon perna. Rata-rata nilai keanekaragaman pada daerah intertidal Desa Haria adalah 0,33 yang digolongkan pada keanekaragaman rendah.

\section{SARAN}

Perlu adanya penelitian lanjutan terkait dengan faktor fisik kimia lingkungan yang mendukung kehidupan tiram pada daerah intertidal Desa Haria.

\section{DAFTAR PUSTAKA}

Dharma, B.1988. Siput dan kerang Indonesia I (Indonesian Shells I). Jakarta: Penerbit PT Sarana Graha. 2005. Recent dan Fosil Indonesia Shell. Indonesia: PT. Ikrar Madiriabadi. Martoyo, J. S., M.A. Nugrohodan T. Wiranto. 2007. Budidaya Teripang. Jakarta: Penerbit Swadaya.

Nontji, A. 1993. Laut Nusantara. Jakarta: Djambatan.

Romimohtarto, K. \& Juwana, S. 2001. Biologi Laut. Jakarta: Penerbit Djambatan.

Odum, E.P. 1998. Dasar-dasar ekologi. Terjemahan T. Samingan dan B. Srigdanono. Yogyakarta: Gajah Mada Press.

Silulu P. F, dkk. 2013. Biodiversitas Kerang Oyster (Mollusca, Bivalvia) Di Daerah Intertidal Halmahera Barat, Maluku Utara. Jurnal Ilmiah Platax, Vol. I-2, Januari 2013, ISSN: 2302-3589, halaman 67-73 